Wrecked ship causes damage to Antarctic ecosystem

\section{Berkeley \& Washington}

THE extent of environmental damage to the Antarctic sea and coastline from the 28 January wreck of an Argentine supply ship is still unclear. The ship, Bahia Paraiso, was carrying an estimated 250,000 gallons of diesel fuel when it ran aground near a US National Science Foundation (NSF) research station on the Antarctic Peninsula, 600 miles south of Cape Horn.

Two miles from Palmer Station, where the 81 tourists on board had visited the US scientists, the ship struck an underwater rock which tore a 30-foot gash in its hull. Staff from Palmer, with help from a number of passing tourist ships, rescued the crew and passengers, but the ship was abandoned. Fuel gushed out forming a slick several centimetres deep, but after

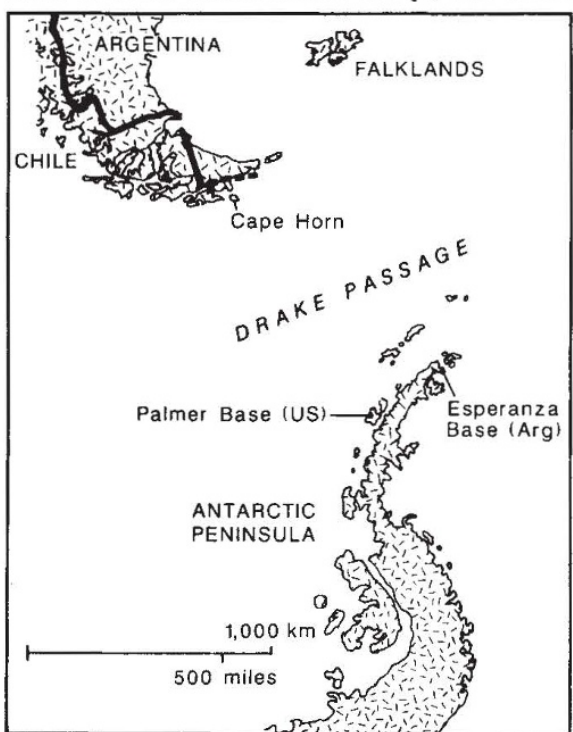

The oil spill near Palmer Station was the first major ecological incident in Antarctica.

this had subsided the ship broke loose of the rock and floated towards the shore, where it spilled more oil along the coast before finally coming to rest. Speaking from Palmer on 3 February, NSF chief scientist Ted DeLaca said that fuel oil was still leaking out at about two gallons a minute. A US Navy ship carrying oil containment booms and recovery equipment was expected to arrive late on 6 February, but in the meantime, an Argentinian vessel arrived last Saturday and picked up salvageable material. Divers from the ship reported that about one-third of the Bahia Paraiso's fuel oil was still in the tanks.

The day after the wreck, researchers at Palmer Station were finding krill and limpets that had been killed by the highly toxic fuel. Polly Penhale, NSF programme director for polar biology, said the spill has endangered the ecological research that has been conducted there for 20 years. Of immediate concern is an Adélie penguin rookery, one of the largest in the area and home to 10,000 breeding pairs. A rapidly conducted survey reported by DeLaca revealed that 38 out of 40 inspected penguins were coated in fuel, and that the mortality rate among skua chicks was perhaps as high as 60 per cent.

The spill was also badly timed for the krill breeding cycle. Young krill hatched in deep water will be rising to the surface in mid-February, so will be exposed to the toxic fuel. DeLaca said that krill in shallow waters near Palmer Station are visibly affected by floating oil, and that several thousand dead krill have been washed up on the beaches, where they are quickly eaten by the penguins.

Diesel fuel presents different problems from a crude oil spill, said David Kennedy, scientific support coordinator for the National Oceanic and Atmospheric Administration's Hazardous Materials Response Branch in Seattle. It does not persist as long as crude oil, but is more toxic. "Diesel, if it hits a biologically sensitive area, has a tendency to kill quickly", said Kennedy, "but not to stay and affect future generations". Cleanup, which involves containment of the spill, followed by soaking or skimming it off the water, will be aided by the relatively warm summer weather and lack of ice floes. Warmth and sunlight will help oxidize and evaporate the uncontained fuel.

Research activities at Palmer Station are likely to turn to a study of the effects of the spill on the ecosystem, information that may be valuable, should Antarctic ship traffic continue to increase.

Members of the Environmental Defense Fund (EDF), who happened to be on the US tour ship that participated in the rescue, have used the incident to underscore their concern about the environmental hazards of increased ship traffic and human activity in the Antarctic, and their opposition to a lifting of the current moratorium on mineral and petroleum exploitation.

DeLaca is concerned that the increasing numbers of tourist visits to the area rely, in such an emergency, on the limited logistical support that scientific bases can supply. Although Palmer Station staff coped successfully with the ship's passengers, and have been able to gather up some of the wreckage, they would have been helpless had the accident occurred a only few more miles away.

Marcia Barinaga \& David Lindley

\title{
New Zealand activists challenge US Navy astronomy station
}

\section{Munich \& Washington}

A LONG-RUNNING dispute over a US Navy observatory in New Zealand is likely to flare up again when the New Zealand government considers peace activists' demands that the observatory be closed.

The US Naval Observatory built the Black Birch observatory on New Zealand's South Island to improve measurements of the fundamental astrometry of the southern sky. Black Birch replaced an older Naval Observatory station at Leoncito, Argentina. According to James Hughes, director of the astrometry department at the Naval Observatory in Washington, $\mathrm{DC}$, the South Island location is better situated for meridian circle measurements, being nearly $10^{\circ}$ further south than the Argentine facility.

But protests against the Black Birch observatory have "plagued" two New Zealand governments since construction began in 1982, according to an official in New Zealand's Ministry of Foreign Affairs. Peace activists claim that the observatory should be closed, and cite a clause in the 1987 New Zealand NuclearFree Zone Law which prohibits New Zealand citizens or residents from "aiding, abetting or procuring any person to manufacture, acquire, possess or have control over any nuclear explosive device".

The leaders of the protest, Scientists Against Nuclear Arms and the Peace Movement Aotearoa, claim that data from the observatory will be used for military purposes. The protesters have called on the government to place the station under civilian management, allowing the current astrometry programme to continue, or, failing that, to close it down.

Hughes says the data being gathered at Black Birch will be used to improve star catalogues, and will be freely available to anyone. But protesters say the observatory provides data for the development of the next generation of Trident submarinebased missiles and for the Strategic Defense Initiative.

The protest movement gained momentum on 29 November, when a public advisory committee established under the Nuclear-Free Zone Law demanded that the New Zealand government reconsider its approval of the project.

A New Zealand Foreign Ministry official said it would be a "surprise" if the government did not respond to the request that Black Birch be shut down soon, possibly at the next advisory committee meeting on 21 February.

Steven Dickman \& Joseph Palca 